\title{
PENGGUNAAN MEDIA QUIZIZZ DALAM PENGUASAAN KOSA KATA BAHASA INGGRIS BAGI KELOMPOK PEMUDA DI GEREJA BETHEL DIASPORA KARANGANYAR JAWA TENGAH
}

\author{
Ch. Evy Tri Widyahening ${ }^{1 *}$, Sumardiono ${ }^{2}$ \\ 1, ${ }^{1,2}$ Universitas Slamet Riyadi Surakarta, Jawa Tengah, Indonesia \\ *Penulis Koresponsensi, email: christiana.widyahening@gmail.com \\ Received:01/11/2021 \\ Revised:13/12/2021 \\ Accepted:15/12/2021
}

\begin{abstract}
English is the first foreign language that must be learned and mastered by everyone, especially students. Its role in the international world is also very important such as in the fields of politics, economy, socio-culture, education, and others. Not only students need to learn English but also the younger generation, especially the youth who are members of the D'Generation group, under the guidance of the Bethel Diaspora Church of Karanganyar, Central Java. Most of them are workers and because they are busy at work, they cannot use English actively or even do not master English. The main element that needs to be learned in English is vocabulary. By mastering English vocabulary, it is certain that learning English will be much easier and more enjoyable. In this case, the use of learning media is very necessary to optimize the process of mastering English vocabulary during this covid 19 pandemic. For this reason, in this training, Quizizz media is used which can be downloaded via the play store on their smartphones. The purpose of this training is to improve the English vocabulary of the youth who are members of the D'Generation group at Bethel Diaspora Church, Karanganyar, Central Java by using the Quizizz media. This training program is carried out for 2 months by online or using Google Meet in meetings. After completing the training program, the youth who participated felt more motivated and able to understand and master English vocabulary well through the fun Quizizz media.
\end{abstract}

Keywords: English Vocabulary, Training, Quizizz

\begin{abstract}
Abstrak. Bahasa Inggris merupakan bahasa asing pertama yang harus dipelajari dan dikuasai oleh semua orang khususnya pelajar. Perannya di dunia internasional juga sangat penting seperti di bidang politik, ekonomi, sosial budaya, pendidikan, dan lain-lain.Tidak hanya siswa saja yang perlu mempelajari bahasa Inggris namun juga para generasi muda khususnya para pemuda yang tergabung dalam kelompok D'Generation yang berada di bawah bimbingan Gereja Bethel Diaspora Karanganyar, Jawa Tengah. Sebagian besar dari mereka adalah pekerja dan karena kesibukan dalam bekerja maka mereka tidak dapat menggunakan bahasa Inggris secara aktif atau bahkan tidak menguasai bahasa Inggris. Unsur utama yang perlu dipelajari dalam bahasa Inggris adalah kosa kata. Dengan menguasai kosa kata bahasa Inggris maka dapat dipastikan bahwa dalam mempelajari bahasa Inggris akan jauh lebih mudah dan menyenangkan. Dalam hal ini, penggunaan media pembelajaran sangat diperlukan untuk mengoptimalkan proses penguasaan kosa kata bahasa Inggris di masa pandemi covid 19 ini. Untuk itu, dalam pelatihan ini maka digunakan media Quizizz yang dapat diunduh melalui play store yang ada di telepon pintar mereka. Tujuan dari pelatihan ini adalah untuk meningkatkan kemampuan kosa kata bahasa Inggris para pemuda yang tergabung dalam kelompok D'Generation di Gereja Bethel Diaspora Karanganyar Jawa Tengah dengan menggunakan media Quizizz. Program pelatihan ini dilaksanakan selama 2 bulan secara daring atau menggunakan google meet dalam pertemuannya. Setelah menyelesaikan program pelatihan, para pemuda yang menjadi peserta merasa lebih termotivasi dan mampu memahami serta menguasai kosa kata bahasa Inggris dengan baik melalui media Quizizz yang menyenangkan.
\end{abstract}

Kata Kunci: Kosa Kata Bahasa Inggris, Pelatihan, Quizizz

How to Cite: Widyahening, C. E.T., \& Sumardiono, S. (2022). Penggunaan Media Quizizz dalam Penguasaan Kosa Kata Bahasa Inggris bagi Kelompok Pemuda di Gereja Bethel Diaspora Karanganyar Jawa Tengah. Mitra Mahajana: Jurnal Pengabdian Masyarakat, 3(1), 1-11. doi: https://doi.org/10.37478/mahajana.v3i1.1311

\section{PENDAHULUAN}

Di era global ini, masyarakat dituntut untuk terus mengembangkan diri seiring dengan perkembangan jaman yang semakin pesat di setiap sektor kehidupan. Mereka dituntut untuk terus belajar dan memperkaya ilmu mereka di bidang mereka masing-masing tanpa terkecuali. Tidak hanya mengembangkan ketrampilan diri melainkan juga mereka harus mengasah ketrampilan berbahasa mereka khususnya bahasa Inggris. Bahasa Inggris menjadi salah satu bahasa internasional yang digunakan oleh masyarakat dunia sebagai alat komunikasi dalam 
berbagai sektor kehidupan seperti politik, pendidikan, hukum, ekonomi, sosial budaya, dan lainlain

Menguasai bahasa Inggris merupakan suatu keharusan bagi masyarakat luas khususnya para pemuda pemudi yang sudah bergelut didunia kerja, khsususnya para pemuda yang tergabung dalam kelompok D'Generation yang berada di bawah naungan Gereja Bethel Diaspora Dagen. Penguasaan bahasa Inggris tersebut sangat penting dimiliki oleh mereka untuk mendukung pekerjaan yang mereka geluti. Penguasaan bahasa Inggris sangat erat didukung oleh salah satu unsur yaitu kosa kata. Dengan mendalami dan menguasai kosa kata bahasa Inggris dengan baik maka hal tersebut menjadi dasar atau langkah awal bagi mereka untuk menguasai bahasa Inggris secara menyeluruh (penguasaan empat ketrampilan berbahasa).

Kosa kata memegang peranan yang sangat penting dalam berkomunikasi antar individu masyarakat dalam bahasa Inggris secara sederhana. Seperti yang dikemukakan oleh Cameron bahwa building up as useful vocabulary is central to the learning of a foreign language at primary level. With vocabulary, learners can learn how to communicate and transfer their ideas through simple expressions (Permatasari, 2019). Melalui kosa kata bahasa Inggris yang baik maka segala aktivitas masyarakat yang dilakukan dengan menggunakan bahasa Inggris dapat berjalan dengan baik dan lancar. Jadi, kosa kata menjadi kunci utama yang tidak boleh dikesampingkan bagi siapa saja yang belajar bahasa. Hal tersebut senada dengan pendapat Zimmerman bahwa vocabulary is central to language and critical importance to the typical language learning. Vocabulary should not be neglected by those who learn a language (Bhakti \& Marwanto, 2018). Sedangkan menurut Ur, 1991) kosa kata dapat didefiniskan sebagai the words we teach in the foreign language. Sedangkan menurut Barnhart (2008), Vocabulary is 1) stock of words used by person, class of people, profession, etc, 2) a collection or list of words, usually in alphabetical order and defined. Sedangkan Fran Lehr, M.A, (2005) menyebutkan bahwa vocabulary as knowledge of words and word meanings in both oral and print language and in productive and receptive forms.

Dari definisi kosa tersebut maka dapat disimpulkan bahwa kosa kata atau vocabulary adalah kumpulan kata ataupun frasa yang biasanya disusun secara berurutan dan diterjemahkan (didefinisikan). Dalam proses pembelajaran, diperlukan media pembelajaran yang menarik apalagi di tengah-tengah pandemi covid 19 yang tengah melanda dunia khususnya Indonesia. Salah satu media pembelajaran yang dapat digunakan di masa pandemi covid 19 ini adalah media pembelajaran elektronik atau e-learning media sebagai sarana proses belajar mengajar. Seperti yang dikemukakan oleh Naidu bahwa e-learning refers to the use of network information and communication technology (ICT) in teaching and learning. E-learning can assist throughout the learning environment of educational activity. The use of e-learning in English teaching takes a fast-paced structure and program of electronic activities for online learning to be successful (Ika Dhamayanti, 2021). Media yang dirasa sangat menarik dan inovatif adalah media permainan. Seperti dikemukakan oleh Irwan bahwa salah satu media pembelajaran yang menarik, memiliki sifat interaktif yang mengutamakan kerjasama, komunikasi, dan bisa menimbulkan interaksi antar siswa adalah melalui permainan, yang mempunyai karakteristik untuk menciptakan motivasi dalam belajar, yaitu khayalan (fantasy), tantangan (challenges) dan keingintahuan (curiosity) (Salsabila et al., 2020). Sedangkan media yang digunakan dalam proses optimalisasi penguasaan kosa kata bahasa Inggris ini adalah media Quizizz.

Quizizz sendiri adalah sebuah perusahaan software kreativitas yang dapat digunakan dalam proses belajar mengajar di kelas, untuk kerja kelompok, review pre-test, ujian, dan tes dadakan. Menurut Zhao Quizizz is a game-like educational application (Zuhriyah \& Pratolo, 2020). Cara penggunaan dari Quizizz sendiri sangat mudah. Di dalamnya terdapat kuis 
interaktif yang berisi 5 pilihan jawaban yang didalamnya terdapat juga jawaban yang benar. Quizizz menjadi salah satu media pembelajaran yang menarik dan inivatif bagi siswa maupun guru. Banyak fitur yang dapatd digunakan saat memakai Quizizz seperti pilihan ganda, isian, maupun uraian. Di tengah pandemi covid 19 ini, penggunaan Quizizz memungkinkan siswa dan guru untuk melakukan pembelajaran online pada waktu yang sama. Dan hal ini, Quizizz juga sangat tepat digunakan dalam kegiatan pengabdian masyarakat. Quizizz menggunakan metode belajar mengajar bergaya kuis di mana pengguna menjawab pertanyaan dalam rangkaian secara mandiri, dan bersaing dengan pengguna lain pada kuis yang sama. Hal tersebut senada dengan pernyataan Purba yaitu Quizizz merupakan aplikasi pendidikan berbasis game, yang membawa aktivitas multi pemain ke ruang kelas dan membuat pembelajaran di kelas menjadi interaktif serta menyenangkan (Asria et al., 2021). Umumnya, yang ditampilkan dalam Quizizz adalah berkaitan dengan kosa kata dan hal tersebut sangat menyenangkan untuk dilakukan karena dapat meningkatkan motivasi belajar dan kerjasama antar siswa. Seperti yang dikemukakan oleh Chaiyo dan Nokham bahwa using Quizizz in the classroom supports learning and increases student engagement, enjoyment, concentration, and motivation (Akhtar et al., 2019).

Dalam kegiatan pengabdian masyarakat ini, para pemuda yang tergabung dalam kelompok D'Generation dapat menggunakan Quizizz di perangkat gadgetnya untuk mengikuti mempelajari kosa kata bahasa Inggris. Sebagai media pembelajaran, Quizizz merupakan alat bantu yang dapat memberikan pengalaman langsung kepada pengguna secara digital. Oleh karena itu, Quizizz sudah banyak digunakan dalam proses belajar mengajar sebagai alat bantu untuk memperkenalkan obyek baru khususnya di masa pandemi corona ini.

\section{METODE PELAKSANAAN}

Sebelum program PKM dijalankan, tahap pertama adalah diadakan persiapan dan pembekalan guna memberikan solusi yang ditawarkan untuk mengatasi permasalahan yang dihadapi para pemuda yang tergabung dalam kelompok pemuda D'Generation Gereja Bethel Diaspora Dagen Karanganyar. Pada tahap persiapan dan pembekalan, mekanisme pelaksanaannya adalah sebagai berikut:

a. Tim pelaksana (Ketua dan Anggota) dan mahasiswa yang membantu program PKM mengikuti pembekalan tentang proses pelaksanaan dari Ketua pelaksana sesuai jadwal yang telah ditetapkan.

b. Tim pelaksana (Ketua dan Anggota) dan mahasiswa mempersiapkan perlengkapan untuk PKM seperti materi pelatihan, media pembelajaran, strategi yang hendak dipakai, dan lainlain.

Lokasi PKM adalah di Gereja Bethel Diaspora Dagen dan dilaksanakan secara daring pada bulan Maret sampai bulan April 2021 setiap hari Minggu dengan para peserta yang berjumlah 13 orang dan merupakan anggota dalam kelompok pemuda D'Generation melalui aplikasi Google Meet. Kegiatan dilaksanakan pada pukul 11:00 sampai pukul 12:00 WIB usai mereka melaksanakan ibadah hari Minggu. Kegiatan memang dilaksanakan pada hari Minggu karena pada hari tersebut sebagian besar dari peserta tidak bekerja.

Metode pelaksanaan yang digunakan dalam pelatihan ini adalah melalui tahapan sebagai berikut:

Pada tahap I, dilakukan identifikasi masalah melalui hasil survei tentang kondisi para pemuda yang tergabung dalam kelompok D'Generation. Di samping itu, identifikasi masalah juga dilakukan melalui wawancara informal dengan beberapa pemuda dalam suatu pertemuan mingguan. 
Pada tahap II, tim pelaksana mengolah semua informasi baik berupa masukan hasil survei dan wawancara. Kajian teoretik dan empiris dikumpulkan terkait dengan usaha memberikan solusi terhadap masalah-masalah yang telah teridentifikasi.

Pada tahap III, dilanjutkan dengan penyusunan materi pelatihan, aplikasi Google Meet untuk pertemuan secara daring, dan media pembelajaran yang digunakan (media sosial Quizizz yang diunduh melalui media Play Store).

Pada tahap IV yang merupakan tahap yang paling penting, tim pelaksana merealisasikan kegiatan ke tempat yang ditentukan untuk melaksanakan pemberdayaan masyarakat. Untuk tujuan ini, tim pelaksana akan berkoordinasi dengan ketua kelompok D'Generation dan pemimpin Gereja agar pelaksanaan kegiatan dapat berjalan lancar. Tahapan dari kegiatan pelatihan meliputi penyemaian informasi, dan pemodelan.

\section{HASIL DAN PEMBAHASAN}

Berdasarkan survei yang dilakukan oleh tim PKM sebelum diadakan sosialisasi dan pelatihan penggunaan media Quizizz dalam penguasaan kosa kata bahasa Inggris, ditemukan bahwa para anggota kelompok D' Generation belum sepenuhnya memahami penggunaan media Quizizz sebagai media pembelajaran kosa kata bahasa Inggris yang sangat mudah dan dapat digunakan melalui gadget setelah diunduh dari playstore. Penggunaan media Quizizz dalam pelatihan ini didasari pula oleh penelitian terdahulu yang dilakukan oleh Pavita dan Nirmala (Pavita \& Nirmala, 2021) yang berjudul "Merdeka Belajar in Pandemic: Using Quizizz Game Based Learning To Improve Students' Vocabulary Mastery". Dari hasil penelitian tersebut disebutkan bahwa penerapan Quizizz menunjukkan bahwa siswa lebih aktif dalam proses pembelajaran sejak mereka saling berlomba untuk menjadi yang pertama menjawab pertanyaan yang diberikan oleh guru di Quizizz. Siswa yang pasif terhadap perintah guru tampak jauh lebih aktif karena mereka tertarik dengan gambar dan lagu yang diberikan oleh guru mereka di Quizizz. Pada penelitian yang dilakukan oleh Nurani dan kawan-kawan (Dwi Cahaya Nurani, Fahmi Surya Adikara, Yanuar Akhmad, 2021) yang berjudul "The Influence of Quizizz Application in Learning Evaluation to Improve College Students' Learning Outcomes". Dari hasil penelitian tersebut disebutkan pula bahwa penggunaan aplikasi Quizizz dapat meningkatkan motivasi belajar mahasiswa. Jadi, bisa disimpulkan bahwa media Quizizz dapat menjadi alternatif media pembelajaran yang inovatif an menyenagkan dalam proses belajar mengajar dan dapat digunakan di segala bidang ilmu apapun, segala jenjang usia, dan jenjang pendidikan, bahkan dapat digunakan pula secara umum oleh masyarakat luas yang ingin belajar dengan menggunakan media Quizizz.

Di dalam pelatihan ini, para peserta merupakan anggota dari kelompok D'Generation yang karena kesibukan bekerja dan aktifitas yang padat, mereka tidak ada waktu untuk belajar kosa kata bahasa Inggris secara mendalam, misalnya dengan membaca buku berbahasa Inggris atau mengikuti kursus bahasa Inggris. Dengan menggunakan gadget pintar mereka, sebenarnya belajar kosa kata bahasa Inggris dapat dilakukan dengan mudah dan menyenagkan, salah satunya dengan mengunduh media Quizizz ini. Dari survei juga diketahui bahwa penggunaan gadget pintar yang mereka miliki lebih banyak digunakan untuk aktifitas bekerja, bermain, dan berselancar di dunia maya atau dimaksudkan untuk memperoleh hiburan (75\%). Sementara $13 \%$ anggota kelompok menyatakan bahwa gadget yang mereka miliki digunakan untuk menambah pengetahuan dan mencari berita-berita nasional maupun berita lokal, $8 \%$ anggota menjawab untuk mengisi waktu luang, dan 7\% lainnya memiliki pandangan bahwa memiliki gadget pintar adalah untuk memperoleh hiburan dan menambah pengetahuan. 
Kegiatan pelatihan ini dilaksanakan di Gereka Bethel Diaspora, Dagen Karanganyar. Obyek sasaran adalah para anggota kelompok pemuda D'Generation yang berjumlah 13 orang dan sebagian besar dari mereka telah bekerja. Kegiatan ini diawali dengan observasi awal ke lokasi dan melakukan wawancara dengan pendeta Daniel yang memimpin jemaat di gereja tersebut dan salah satu pengurus kelompok pemuda D'Generation. pada tanggal 26 Februari 2021. Kondisi yang dijumpai di lokasi adalah ruang pertemuan yang menyatu dengan tempat iabadah jemaat dan ruang pendeta. Untuk kegiatan kepemudaan, kegiatan tersebut dilaksanaan setelah kegiatan ibadah selesai yaitu pada hari Minggu siang. Kegiatan yang dilakukan oleh para anggota kelompok D'Generation biasanya adalah sharing pengalaman selama seminggu, bernyanyi, berdoa, dan lain-lain. Untuk acara yang berkaitan dengan pelatihan bahasa Inggris belum pernah dilakukan di gereja tersebut khususnya bagi kelompok pemuda D'Generation. Terlebih lagi, Sebagian besar anggota menganggap bahwa bahasa Inggris sulit untuk dipelajari dan 'menakutkan', dan mereka malas untuk mempelajarinya atau bahkan menguasainya.
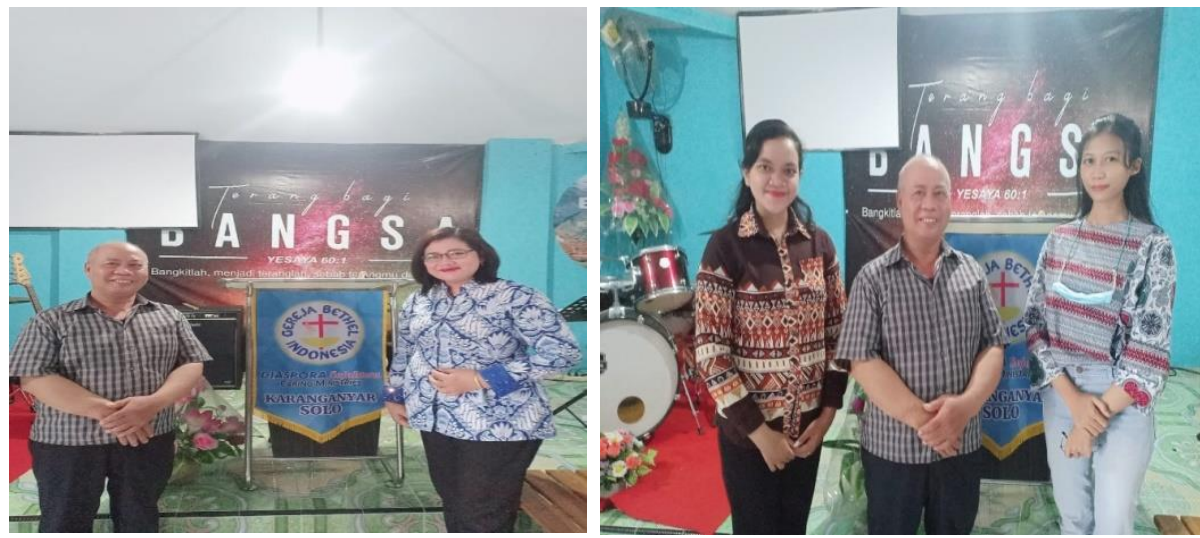

Gambar 1 \& 2. Observasi awal dan wawancara dengan pengurus Gereja Bethel Diaspora

Berdasarkan hal tersebut maka tim PKM mencoba untuk mencari pemecahannya agar minat mereka untuk belajar dan menguasai bahasa Inggris khususnya kosa kata bahasa Inggris dapat meningkat sehingga tujuan utama yaitu learning vocabulary for pleasure menjadi terwujud. Selanjutnya, pada tanggal 28 Februari 2021 tim PKM melaksanakan sosialisasi kegiatan yang hendak dilaksanakan di Gereja Bethel Diaspora Dagen Karanganyar yang ditujukan pada kelompok pemuda D'Generation. Sosialisasi ini bertujuan agar para anggota D'Generation dapat ikut terlibat aktif dalam setiap kegiatan pelatihan yang dilaksanakan oleh tim PKM secara daring. Pelaksanaan pelatihan ini disesuaikan dengan waktu atau jam kerja para anggota dan akhirnya disepakati setiap Minggu. Sebelum diadakan pelatihan, mereka diminta untuk terlebih dahulu mengunduh aplikasi Quizizz melalui Playstore yang sudah ada di setiap gadget mereka. Kegiatan sosialisasi ini berlangsung sangat akrab walaupun dilakukan secara daring (melalui google meet). Mereka juga menganggap bahwa kegiatan pelatihan bahasa Inggris ini akan membawa nilai tambah untuk mereka yaitu mereka menjadi mampu untuk menguasai kosa kata bahasa Inggris dan mengaplikasikannya dalam kegiatan keseharian mereka khususnya dalam menunjang pekerjaan di tempat kerja mereka. Kegiatan pelatihan ini dilaksanakan pada tanggal 7 Maret sampai tanggal 18 April 2021 secara daring melalui Google Meet karena kondisi pada saat dilaksanakan pelatihan masih berada dalam situasi pandemi covid 19 yang tidak memungkinkan untuk dilaksanakan pelatihan secara tatap muka atau luring. 
Sebelum diadakan pelatihan, ketua PKM melaksanakan briefing bersama para anggota tim pada tanggal 1 Maret 2021 mengenai kegiatan pelatihan yang akan dilaksanakan. Pada briefing tersebut dibicarakan tentang pembagian tugas dalam pelatihan kosa kata bahasa Inggris dengan menggunakan media Quizizz secara daring melalui Google meet. Kegiatan ini tidak hanya sekedar memberikan materi pelatihan bahasa Inggris tentang kosa kata namun juga diadakan praktek dengan menggunakan media Quizizz yang sebelumnya sudah diunduh oleh para peserta pelatihan.
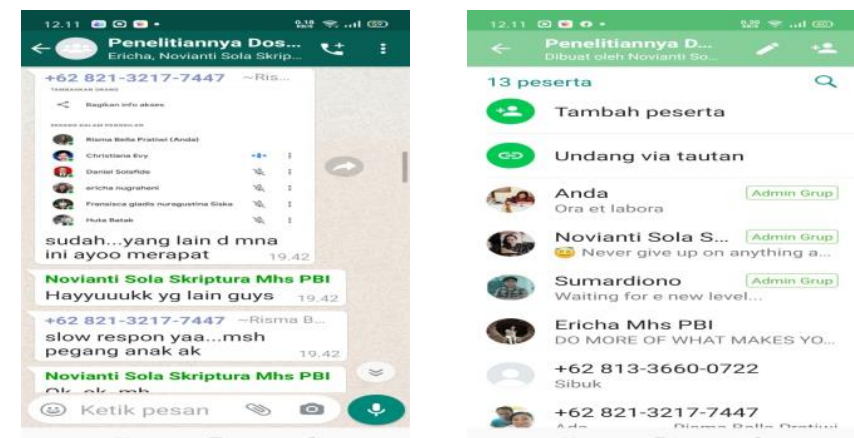

Gambar 3 \& 4. Grup WA yang digunakan untuk memudahkan kegiatan pelatihan dan informasi terkait kegiatan pelatihan

Pada tanggal 7 Maret 2021, pemateri pertama memberikan materi kosa kata bahasa Inggris terkait tentang bagaimana mempelajari kosa kata bahasa Inggris dengan mudah dan menyenangkan di tengah era digital ini. Selain itu, pemateri pertama juga memberikan penjelasan tentang kosa kata bahasa Inggris yang secara umum sering digunakan dalam percakapan sehari-hari yang sederhana meliputi kata sifat, kata ganti, kata keterangan, kata benda, kata kerja, preposisi, dan lain-lain. Pada pelatihan hari pertama ini, pemateri lebih banyak memberikan penjelasan terkait dengan peran kosa kata bahasa Inggris dalam bahasa lisan maupun bahasa tulis dan melakukan tanya jawab dengan para peserta seputar pengalaman mereka menggunakan bahasa Inggris dan sejauhmana pemahaman mereka tentang kosa kata bahasa Inggris. Jawaban mereka bervariasi. Namun sebagian besar dari mereka memberikan jawaban bahwa bahasa Inggris yang mereka peroleh terakhir adalah saat masih duduk di bangku SMA sehingga saat ini mereka sudah lupa bagaimana caranya berbahasa Inggris. Hal itu disebabkan karena tidak pernahnya bahasa Inggris digunakan secara aktif atau bahkan secara pasif dalam lingkungan kerja mereka.
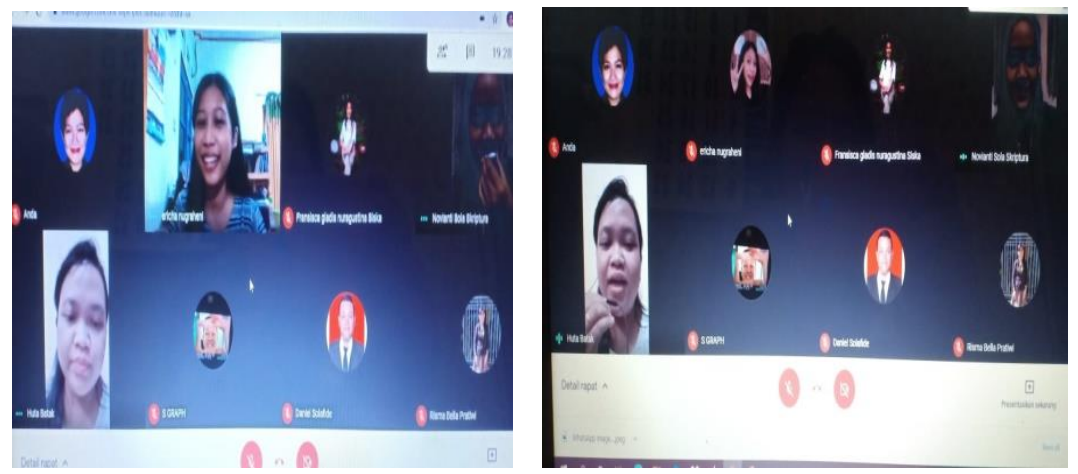

Gambar 5 \& 6. Pelatihan hari pertama tanggal 1 Maret 2021 dan tanya jawab dengan peserta

Pada pelatihan hari kedua yaitu tanggal 14 Maret 2021, pemateri pertama memberikan penjelasan tentang berbagai media yang dapat digunakan untuk mempelajari bahasa Inggris 
khususnya kosa kata bahasa Inggris. Salah satu yang diperkenalkan kepada para peserta adalah media Quizizz yangmana merupakan salah satu media yang cukup mudah untuk digunakan sebagai media pembelajaran bahasa Inggris bagi peserta. Selanjutnya, diadakan latihan untuk menebak sebuah kata dalam bahasa Inggris dengan menggunakan media Quizizz. Tema yang diberikan dalam latihan ini adalah Nouns atau kata benda, Verbs atau kata kerja, dan Adjective atau kata sifat. Sebelumnya, para peserta diminta untuk mengunduh aplikasi Quzizz melalui PlayStore. Quizizz sendiri adalah alat belajar mandiri yang dapat membantu setiap orang khususnya siswa untuk menikmati proses belajar mengajar mereka secara menyenangkan dan dapat digunakan dari pendidikan tingkat TK sampai perguruan tinggi bahkan dapat digunakan untuk masyarakat umum yang tertarik belajar kosa kata bahasa Inggris. Kegiatan tersebut dirasakan sangat menyenangkan oleh para peserta karena media Quizziz di kemas dengan sangat menarik dalam bentuk permainan yang hasil akhirnya langsung dapat mereka peroleh. Artinya adalah aplikasi Quizizz ini memiliki manfaat yang besar sebagai media pembelajaran dan juga sebagai bahan evaluasi pembelajaran yang hasilnya dapat menggambarkan tentang sejauh mana pemahaman peserta didik terhadap materi yang diberikan oleh guru dengan cara yang menarik dan menyenangkan. Hal tersebut senada pula dengan pendapat Wahyudi, Rufiana dan Nurhidayah bahwa Quizizz sangat memotivasi siswa untuk lebih semangat mengerjakan dengan hati-hati sehingga mampu memperoleh rangking yang bagus dan maksimal. Apabila siswa mengerjakan soal dengan benar, maka Quizizz juga memberikan reward berupa tambahan waktu untuk mengulang soal-soal yang telah dikerjakan dengan jawaban yang salah. Tidak hanya itu, reward yang diberikan Quizizz juga berupa menghilangkan dua pilihan jawaban yang salah, sehingga siswa lebih mudah untuk menentukan jawaban yang benar (Wahyudi et al., 2020). Dalam kegiatan ini, pemateri memberi contoh terlebih dahulu tentang bagaimana menggunakan Quizizz dan pada akhirnya mereka ikuti dengan mengerjakan soal yang ada di aplikasi Quizizz dengan tema Nouns atau kata benda, Verbs atau kata kerja, dan Adjective atau kata sifat.

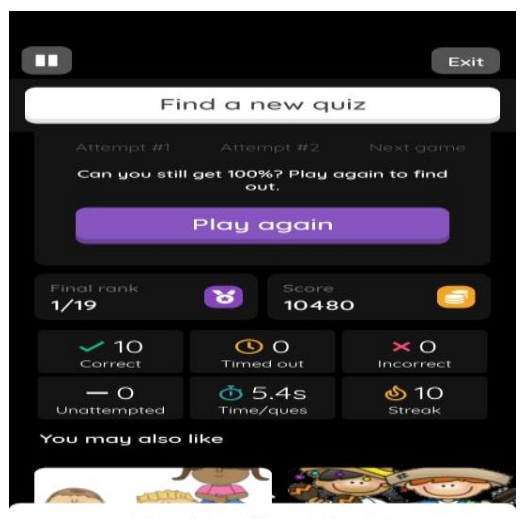

Review euestions

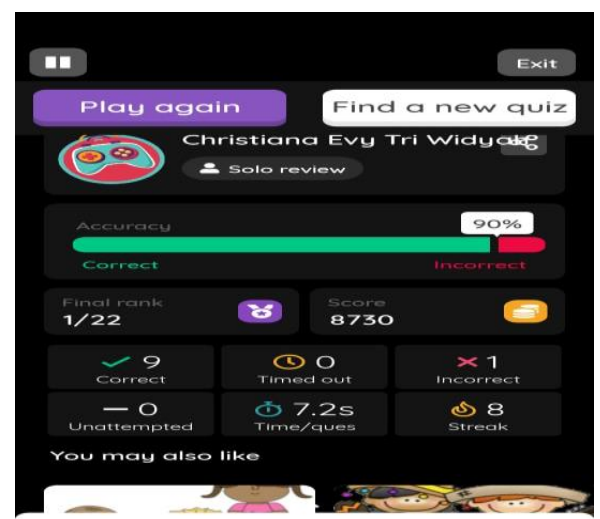

Review Questions

Gambar 7 \& 8. Dua contoh hasil kinerja para peserta dalam mengerjakan soal melalui Quizizz

Pada tanggal 21 Maret 2021, pemateri kedua memberikan pelatihan berikutnya dengan tema Antonym atau lawan kata dan Synonym atau padan kata melalui media Quizizz. Sebelum diadakan latihan dengan menggunakan Quizizz, peserta diberi penjelasan terlebih dahulu tentang perbedaan antara Antonym dan Synonym dalam bahasa Inggris dan membandingkannya dengan Antonim dan Sinonim dalam bahasa Indonesia beserta contohcontohnya. Kegiatan ini juga dilanjutkan dengan tanya jawab dengan para peserta. 


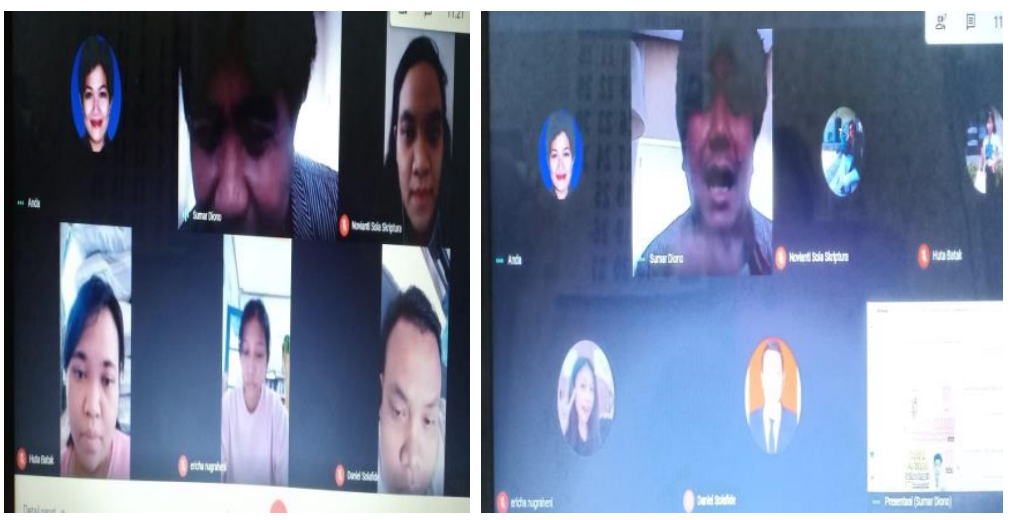

Gambar 9 \& 10 pemateri kedua memberikan paparan materi dan tanya jawab dengan peserta

Pada tanggal 28 Maret 2021, pelatihan kosa kata bahasa Inggris berikutnya dilaksanakan dengan tema tentang Foods atau makanan dan Beverages atau minuman. Seperti sebelumnya, para peserta diberi penjelasan terlebih dahulu tentang tema yang hendak dibahas pada pelatihan hari ini. Mereka juga diajak untuk menyebutkan berbagai makanan dan minuman lokal maupun internasional yang ada di sekitar mereka. Mereka juga diajak berbagi pengalaman dalam menikmati cita rasa makanan dan minuman tersebut. Selanjutnya, pemateri memberikan contoh-contoh makanan dan minuman baik lokal maupun internasional yang sudah banyak menjamur di sekitar mereka dalam bahasa Inggris. Berikutnya, para peserta diminta untuk mengerjakan kembali soal bahasa Inggris yang ada di media Quizizz dengan tema Foods and Beverages. Dan hasilnya dibagikan melalui grup WA sehingga peserta lainnya dapat melihat perkembangan mereka dalam pelatihan ini.

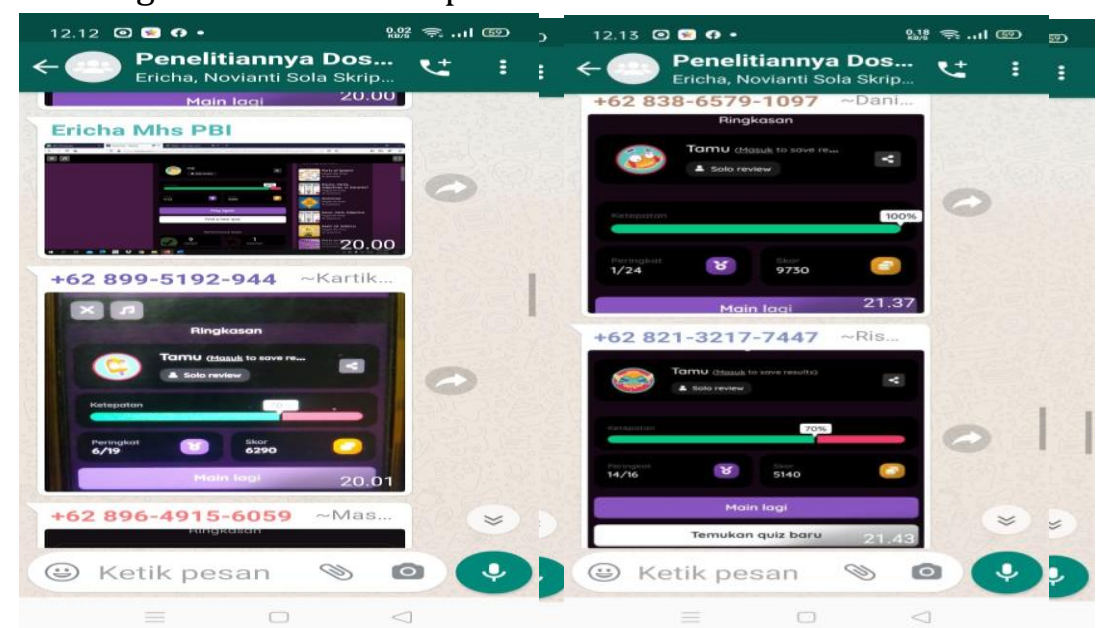

Gambar 11 \& 12. Hasil kinerja kosa kata bahasa Inggris para peserta dengan menggunakan media Quizziz yang dibagikan melalui grup WA.

Pada tanggal 18 April 2021, pelatihan kosa kata bahasa Inggris berikutnya dilaksanakan dengan tema tentang Jobs atau pekerjaan dan Routines atau kegiatan sehari-hari. Di awal pelatihan, pemateri memberikan penjelasan terselih dahulu tentang tema yang akan diberikan kepada para peserta yaitu tentang jobs and routines. Seperti sebelumnya, mereka diminta untuk menyebutkan berbagai pekerjaan yang mereka ketahui dan menjelaskan deskripsi pekerjaanpekerjaan tersebut. Pemateri juga meminta mereka menyebutkan pekerjaan mereka masingmasing dan mendeskripsikan apa dan bagaimana pekerjaan mereka. Berikutnya, para peserta diminta untuk mengerjakan latihan bahasa Inggris yang ada di media Quizizz dengan tema Jobs 
and Routines. Dan hasilnya pun dibagikan melalui grup WA agar supaya peserta lainnya dapat melihat hasil yang telah dicapai tiap peserta dalam pelatihan ini.

Kegiatan Pengabdian Kepada Masyarakat ini diakhiri pada tanggal 25 April 2021 secara daring melalui Google Meet yangmana para peserta pelatihan memberikan kesan dan pesan terhadap kegiatan yang sudah dilaksanakan ini. Pada dasarnya, mereka sangat senang dan menganggap bahwa pelatihan ini sangat bermanfaat serta dapat menunjang pekerjaan mereka. Apalagi, dengan adanya aplikasi Quizizz ini mereka dengan sangat mudah dapat berlatih kosa kata bahasa Inggris dimana saja dan kapan saja. Selain itu, mereka juga merasa memperoleh pengetahuan baru terkait penggunaan media belajar lainnya yang dapat diunduh melalui media Play Store yang sudah ada di gadget pintar mereka. Media-media belajar tersebut juga sangat menarik dan sangat membantu mereka dalam menguasai kosa kata bahasa Inggris. Mereka berharap bahwa pelatihan serupa dapat dilaksanakan kembali dengan menggunakan media belajar lainnya yang lebih menarik dan dapat dilaksanakan secara tatap muka langsung atau luring setelah pandemi covid 19 berakhir.
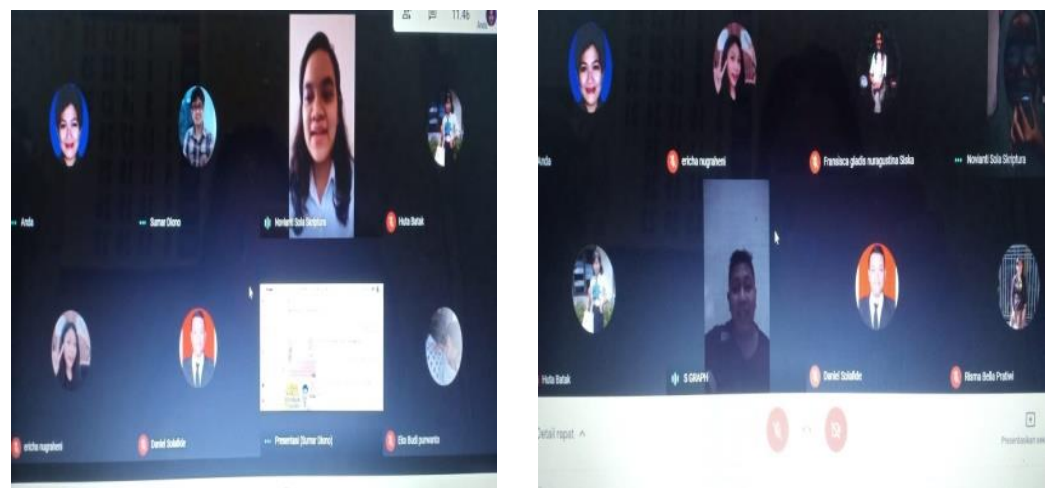

Gambar 13 \& 14. Para peserta memberi kesan dan pesan di hari terakhir kegiatan PKM

\section{SIMPULAN DAN TINDAK LANJUT}

Kegiatan pelatihan kosa kata bahasa Inggris dengan media Quizizz secara daring dapat dilaksanakan dengan baik tanpa kendala yang berarti. Meskipun ada kendala jaringan namun hal tersebut masih dapat teratasi dengan baik. Kegiatan pelatihan pun berjalan menyenangkan karena kegiatan dilaksanakan dengan media Quizizz yang sangat menarik dan menjadi pengalaman pertama bagi para peserta untuk menggunakannya sebagai media pembelajaran kosa kata bahasa Inggris.

Motivasi para peserta dalam belajar kosa kata juga meningkat apalagi sebelum dilaksanaka latihan, mereka diajak untuk berbagi pengalaman terlebih dahulu berkaitan dengan tema yang diberikan. Mereka juga diminta untuk membuat kalimat bahasa Inggris yang didalam kalimat tersebut mengandung salah satu kosa kata yang berhasil mereka sebutkan dengan benar. Selama kegiatan berlangsung, para peserta aktif dalam bertanya dan menjawab pertanyaan yang diberikan oleh pemateri. Mereka juga sangat senang manakala melihat hasil yang ditunjukkan setelah berhasil menyelesaikan soal latihan yang ada pada media Quizizz. Walaupun dilaksanakan secara daring melalui Google Meet, namun hal tersebut tidak menghalangi antusiasme mereka dalam mengikuti pelatihan ini dengan menggunakan medis Quizizz. 
Pelatihan ini telah memberikan pengalaman positif bagi para peserta yang tergabung dalam kelompok pemuda D'Generation. Mereka semakin termotivasi untuk belajar bahasa Inggris apalagi setelah memperoleh penjelasan bahwa banyak media belajar bahasa Inggris yang mudah dan menarik serta dapat diunduh secara gratis melalui Play Store. Sehingga hal tersebut menjadi pendorong mereka untuk belajar bahasa Inggris dengan mudah dimana saja dan kapan saja melalui gadget pintar mereka. Salah satu media belajar yang mudah dan menyenangkan dan dapat digunakan adalah Quizizz. Kegiatan ini diharapkan dapat dilaksanakan secara terjadwal mengingat tidak hanya kelompok pemuda D'Generation saja yang memerlukan pelatihan bahasa Inggris namun ada juga kelompok-kelompok pemuda yang ada di sekitar Gereja Bethel Diapora Karnganyar. Pelatihan terjadwal lainnya yang mungkin dapat diberikan dan diharapkan dapat menambah pemahaman mereka terhadap bahasa Inggris adalah pelatihan ketrampilan berbicara atau Speaking Skill yang pastinya sangat berguna dan bagi para pemuda guna mendukung profesi mereka di dunia kerja.

\section{DAFTAR PUSTAKA}

Akhtar, H., Hasanati, N., \& Istiqomah, I. (2019). Game-Based Learning: Teachers' Attitude and Intention To Use Quizizz in the Learning Process. 2nd International Conference on Educational Assessment and Policy (ICEAP 2019), Iceap, 49-54. https://doi.org/10.26499/iceap.v0i0.202

Asria, L., Sari, D. R., Ngaini, S. A., Muyasaroh, U., \& Rahmawati, F. (2021). Analisis Antusiasme Siswa Dalam Evaluasi Belajar Menggunakan Platform Quizizz. Alifmatika: Jurnal Pendidikan Dan Pembelajaran Matematika, 3(1), 1-17. https://doi.org/10.35316/alifmatika.2021.v3i1.1-17

Barnhart, Cynthia A. (2008). The Fact on File Student's Dictionary of American English. Fact on File, Inc.

Bhakti, S. O., \& Marwanto, M. M. (2018). Vocabulary Mastery by Using Storytelling. Script Journal: Journal of Linguistic and English Teaching, 3(1), 79. https://doi.org/10.24903/sj.v3i1.146

Chaer, Abdul. 2007. Linguistik Umum. Jakarta: Rineka Cipta.

Nurani, D. C., Adikara, F. S., \& Akhmad, Y. THE INFLUENCE OF QUIZIZZ APPLICATION IN LEARNING EVALUATION TO IMPROVE COLLEGE STUDENTS'LEARNING OUTCOMES. JURNAL PAJAR (Pendidikan dan Pengajaran), 5(4), 890-896.

Fran Lehr, M.A. \& Associates. 2005. A Focus on Vocabulary. Honolulu: Pasific Resources for Education and Learning.

Ika Dhamayanti, F. (2021). EFL Students' Perception and Motivation Toward Quizizz as ELearning Media in English E-Classroom. Education of English as Foreign Language, 4(2), 71-78. https://doi.org/10.21776/ub.educafl.2021.004.02.03

Lyons, John. (1972). Language and Linguistics: An Introduction. New York: Cambridge University Press

Pavita, M. D. A., \& Nirmala, D. N. (2021). Merdeka Belajar in Pandemic: Using Quizizz Game Based Learning To Improve Students' Vocabulary Mastery. Language Literacy: Journal of Linguistics, Literature, and Language Teaching, 5(1), 221-227. https://doi.org/10.30743/ll.v5i1.3842

Permatasari, Y. D. (2019). Using Top and Tail Game to Improve Students' Vocabulary Mastery. 
ELLITE: Journal of English Language, Literature, and Teaching, 4(2), 73.

https://doi.org/10.32528/ellite.v4i2.2988

Salsabila, U. H., Habiba, I. S., Amanah, I. L., Istiqomah, N. A., \& Difany, S. (2020). Pemanfaatan Aplikasi Quizizz Sebagai Media Pembelajaran Ditengah Pandemi Pada Siswa SMA. Jurnal Ilmiah Ilmu Terapan Universitas Jambi|JIITUJ/, 4(2), 163-173.

https://doi.org/10.22437/jiituj.v4i2.11605

Ur, Penny. (1991). A Course in Language Teaching. Cambridge: Cambridge University Press.

Wahyudi, W., Rufiana, I. S., \& Nurhidayah, D. A. (2020). Quizizz: Alternatif Penilaian di Masa Pandemi Covid-19. Jurnal Ilmiah Soulmath : Jurnal Edukasi Pendidikan Matematika, 8(2), 95. https://doi.org/10.25139/smj.v8i2.3062

Zuhriyah, S., \& Pratolo, B. W. (2020). Exploring students' views in the use of quizizz as an assessment tool in english as a foreign language (efl) class. Universal Journal of Educational Research, 8(11), 5312-5317. https://doi.org/10.13189/ujer.2020.081132 